\title{
The efficacy and safety of intravenous thrombolysis with alteplase in the treatment of ischaemic stroke in a rural hospital
}

\section{Skuteczność i bezpieczeństwo trombolizy dożylnej za pomocq alteplazy w leczeniu udaru niedokrwiennego mózgu w szpitalu w regionie rolniczym}

Piotr Sobolewski, Monika Śledzińska-Dźwigał, Wiktor Szczuchniak, Renata Hatalska-Żerebiec, Marcin Grzesik, Anna Sobota

Sandomierski Ośrodek Neurologii z Oddziałem Neurologii i Oddziałem Udarowym, SPZOZ w Sandomierzu

Neurologia i Neurochirurgia Polska 2013; 47, 4: 310-318

DOI: 10.5114/ninp.2013.36755

\begin{abstract}
Background and purpose: Ongoing evaluation of the results of thrombolytic therapy in patients with ischaemic stroke (IS) in regions with different health care organization is absolutely crucial for making this method of treatment safer and efficient. The aim of this study was to analyse the efficacy and safety of treatment with intravenous alteplase in patients with acute IS in a rural hospital.

Material and methods: Between 2006 and 2011, 1392 patients with IS were treated (including 200 patients treated with alteplase; $14.37 \%$ ). In patients treated with alteplase, we analysed the influence of several variables on the functional status after 3 months according to the modified Rankin Scale (mRS), case-fatality rate during 3 months after onset and symptomatic intracerebral haemorrhage (SICH).

Results: In the studied population, good outcome (mRS $0-2)$ at 3 months was related to younger age $(p=0.001)$, male $\operatorname{sex}(p=0.02)$ and low scores $(<15$ points $)$ on the National Institutes of Health Stroke Scale (NIHSS) $(p<0.0001)$. Deaths within 3 months were related to older age $(p=0.027)$, female sex $(p=0.004)$, severity of stroke measured by NIHSS score $(p<0.0001)$ and presence of radiological signs of previous stroke in baseline computed tomography (CT) $(p=0.002)$. Patients with SICH had higher mean age $(p=0.014)$ and higher severity of neurological deficit measured on the NIHSS scale $(p=0.03)$.
\end{abstract}

\section{Streszczenie}

Wstęp i cel pracy: Prowadzenie ciąłłej oceny wyników leczenia trombolitycznego chorych na udar niedokrwienny mózgu (UNM) w regionach różniących się organizacją ochrony zdrowia ma duże znaczenie dla skuteczniejszego oraz bezpieczniejszego stosowania tej metody. Celem pracy była analiza skuteczności i bezpieczeństwa leczenia podawaną dożylnie alteplazą u chorych na UNM w szpitalu w regionie rolniczym. Materiał i metody: W latach 2006-2011 autorzy leczyli 1392 chorych na UNM - alteplazę otrzymało 200 pacjentów $(14,37 \%)$. W grupie chorych leczonych alteplazą przeanalizowano wpływ wielu czynników na stan funkcjonalny po 3 miesiącach, uwzględniając punktację w zmodyfikowanej skali Rankina (mRS), częstość zgonów w ciągu 3 miesięcy od zachorowania oraz częstość objawowych krwotoków śródmózgowych (SICH).

Wyniki: W badanej populacji dobry wynik leczenia (mRS $0-2)$ po 3 miesiącach wiązał się $z$ młodszym wiekiem chorych $(p=0,001)$, płcią męską $(p=0,02)$ i małą $(<15$ pkt) punktacją w Skali Udarowej Narodowych Instytutów Zdrowia (NIHSS) $(p<0,0001)$. Zgony w ciągu 3 miesięcy były istotnie częstsze wśród osób starszych $(p=0,027)$, kobiet ( $p=0,004)$, osób z dużym nasileniem ubytkowych objawów neurologicznych w skali NIHSS $(p<0,0001)$ i u osób z objawami przebytego udaru w wyjściowej tomografii komputerowej (TK) $(p=0,002)$. Grupa chorych z SICH cechowała się

Correspondence address: Piotr Sobolewski, Sandomierski Ośrodek Neurologii z Oddziałem Neurologii i Oddziałem Udarowym, Szpital Specjalistyczny Ducha Świętego w Sandomierzu, ul.Schinzla 13,27-600 Sandomierz, e-mail: piotrsobolewski@poczta.onet.pl

Received: 28.01.2012; accepted: 29.11.2012 
Conclusions: The indications for intravenous thrombolysis in patients with IS should be strictly analysed so that the treatment is effective and safe especially in older patients, patients with greater severity of neurological symptoms and patients with old post-stroke lesions in baseline CT.

Key words: ischaemic stroke, treatment with alteplase, rural region.

\section{Introduction}

Stroke is the third leading cause of death in the United States, Canada, Europe and Japan. The American Heart Association and American Stroke Association estimate that approximately 800000 new strokes occur each year, resulting in more than 130000 annual deaths in the United States alone [1]. The incidence of stroke in Poland is similar to that in other European countries (the incidence rate is 177/100 000 in males and 125/100 000 in females). Half of these patients die within one year, while the remaining one-half have permanent consequences within the central nervous system [2,3]. According to the Ministry of Health, about 88500 hospitalizations with a diagnosis of stroke were reported in 2007 in Poland (data may be underestimated by about 15\%) [4].

Ischaemic stroke (IS) is not a single disease but a heterogeneous condition with several very different pathophysiological mechanisms. Identification of the underlying cause is important for selecting patients for some specific therapies. One of the most significant advances during the last two decades has been the introduction of intravenous thrombolysis as a standard therapy for the well-selected population of patients with acute IS. Intravenous recombinant tissue plasminogen activator (rt-PA, alteplase) was approved by the Food and Drug Administration (FDA) based on the results of the National Institute of Neurological Disorders and Stroke (NINDS) trial in 1996 in the United States and later in Canada, Japan, countries of South America and Australia [5]. The temporary European license was granted in 2003 and a European registry of all thrombolysis procedures, Safe Implementation of Thrombolysis in Stroke - Monitoring Study (SITS-MOST), was created at the same time [6]. In 2003, under the same condition as in other European countries, alteplase temporary approval was granted [7]. The benefits of intravenous thrombolysis are therefore greatest when treatment is initiated early following stroke onset [8]. Until 2008, an upper większą średnią wieku ( $p=0,014)$ i większym nasileniem objawów neurologicznych mierzonych skalą NIHSS $(p=0,03)$. Wnioski: Należy ściśle analizować wskazania do dożylnej trombolizy u chorych na UNM, aby leczenie było skuteczne i bezpieczne, w szczególności u chorych starszych, chorych ze znacznym nasileniem objawów neurologicznych i chorych z obecnością starych ognisk poudarowych w wyjściowej TK.

Słowa kluczowe: udar niedokrwienny mózgu, leczenie alteplazą, region rolniczy.

limit of 3 hours for routine use of alteplase in a dose of $0.9 \mathrm{mg} / \mathrm{kg}$ after IS was recommended. The third ECASS (European Cooperative Acute Stroke Study) trial found that intravenous alteplase administered between 3 and 4.5 hours after the onset of symptoms significantly improved clinical outcomes in patients with acute IS [9]. The SITS register has shown that treatment at an average of 3 hours 15 minutes and until 4.5 hours after stroke onset remains as safe as earlier treatment in routine clinical practice [10]. In Poland, the drug has been officially approved for use in a time window of up to 4.5 hours since September $2010[11,12]$.

The aim of this study was to analyse the safety and efficacy of intravenous thrombolysis in a group of patients with acute IS. All patients treated in the Stroke Unit Department of Neurology Hospital in Sandomierz were reported to the SITS registry according to the protocol.

The retrospective evaluation of efficacy and safety of treatment of patients with a given method may allow the selection of a group of patients in whom this method will be of greatest benefit.

\section{Material and methods}

The stroke unit in the hospital in Sandomierz takes care of a 200 thousand population and cooperates in this field with five neighbouring hospitals. Two of them have neurological departments, but without stroke units. Fifty percent of our patients were recruited for the treatment with thrombolytic therapy from areas of neighbouring hospitals. Our centre was recognized as a stroke unit according to the Polish national criteria and equipped with proper monitoring and diagnostic facilities [13]. We analysed the neurological status of the patients at the moment of admission and 3 months after symptoms onset according to the National Institutes of Health Stroke Scale (NIHSS) [14] and functional outcome at 3 months after symptoms onset according to the modified Rankin Scale (mRS) [15]. All patients had com- 
Table 1. Characteristics of the study group

\begin{tabular}{|c|c|}
\hline \multicolumn{2}{|l|}{ Variable* } \\
\hline \multicolumn{2}{|l|}{ Sex } \\
\hline Women & $88(44 \%)$ \\
\hline Men & $112(56 \%)$ \\
\hline Age [years]; mean $\pm \mathrm{SD}$ (range) & $69.1 \pm 10.6(41-92)$ \\
\hline $\mathrm{rt}-\mathrm{PA}$ dose $[\mathrm{mg}] ;$ mean $\pm \mathrm{SD}$ & $64.2 \pm 12.8$ \\
\hline $\begin{array}{l}\text { Onset-to-needle time [min]; } \\
\text { mean } \pm \text { SD (range) }\end{array}$ & $150.5 \pm 41.2(45-270)$ \\
\hline $\begin{array}{l}\text { Door-to-needle time }[\mathrm{min}] \\
\text { mean } \pm \mathrm{SD} \text { (range) }\end{array}$ & $63.7 \pm 28.8(10-190)$ \\
\hline $\begin{array}{l}\text { Baseline NIHSS score; } \\
\text { mean } \pm \text { SD }\end{array}$ & $12.3 \pm 5.0$ \\
\hline $0-7$ & $43(21.5 \%)$ \\
\hline $8-14$ & $90(45 \%)$ \\
\hline$\geq 15$ & $67(33.5 \%)$ \\
\hline \multicolumn{2}{|l|}{ OCSP classification } \\
\hline TACI & $54(27 \%)$ \\
\hline PACI & $102(51 \%)$ \\
\hline LACI & $43(21.5 \%)$ \\
\hline POCI & $1(0.5 \%)$ \\
\hline \multicolumn{2}{|l|}{ Prevalence of risk factors } \\
\hline Hypertension & $134(67 \%)$ \\
\hline Diabetes mellitus & $25(12.5 \%)$ \\
\hline Dyslipidaemia** & $154(77 \%)$ \\
\hline Atrial fibrillation & $68(34 \%)$ \\
\hline Previous stroke & $33(16.5 \%)$ \\
\hline Coronary heart disease & $105(52.5 \%)$ \\
\hline Previous smoker & $36(18 \%)$ \\
\hline Current smoker & $40(20 \%)$ \\
\hline
\end{tabular}

* Data are numbers (\%) unless otherwise stated.

**According to European guidelines on cardiovascular disease prevention in clinical practice SD - standard deviation, NIHSS - National Institutes of Health Stroke Scale, OCSP Oxford Community Stroke Project, TACI - total anterior circulation infarct, PACI - partial anterior circulation infarct, LACI - lacunar infarct, POCI - posterior circulation infarct

puted tomography (CT) of the brain performed: prior to treatment, 22-36 hours after the start of treatment and at the seventh day. The patients had additional CT in the case of neurological deterioration rated as $\geq 4$ points on the NIHSS.

Early signs of infarction were interpreted according to von Kummer et al. [16]. Cerebral oedema was classified according to the SITS Monitoring Study (SITS-
MOST) Final Study Protocol [17]. We used the ECASS protocol definition of symptomatic intracerebral haemorrhage (SICH) [18].

We analysed the impact of various factors on the efficacy and safety of treatment with alteplase. We compared groups of patients with good (mRS 0-2) and poor (mRS 3-6) outcome, groups of patients who died within 3 months after stroke onset and survivors, as well as groups of patients with or without SICH.

The ethics committee approved of our approach to ascertain and analyse data of all alteplase-treated stroke patients.

\section{Statistical methods}

Statistical analysis was done with Statistica 6.0. Univariate analyses were performed and $\chi^{2}$ tests with appropriate corrections (Yates correction, maximum-likelihood $\chi^{2}$ Fisher exact test) for sample size and expected counts and nonparametric Mann-Whitney $U$-test were used. The level of significance was set at $p<0.05$. Additionally, odds ratios (OR) with $95 \%$ confidence intervals (CI) were estimated.

\section{Results}

Between September 2006 and March 2011, 1392 patients with acute IS were treated in the stroke unit in Sandomierz, including 200 Caucasian patients (aged 41-92, mean $69.07 \pm 10.57)$ treated with rt-PA (14.37\%). Demographic data, clinical data including risk factors, baseline NIHSS score, logistic times, and type of stroke according to the Oxfordshire Community Stroke Project Classification (OCSP) are given in Table 1.

There were more patients with heart disease, especially with atrial fibrillation, in our study population.

Radiological signs of an old and current stroke in baseline CT and the incidence of haemorrhagic transformation, SICH and cerebral oedema in control CT are shown in Table 2.

Baseline CT was normal in $36 \%$ of patients; it revealed signs of previous stroke in $36.5 \%$, and signs of current stroke in $27.5 \%$ of patients. Control CT showed haemorrhagic transformation in $17.5 \%$ of patients, $\mathrm{SICH}$ in $5 \%$ and cerebral oedema in $32 \%$.

After 3 months, we found a good outcome (mRS $0-2)$ in $58.0 \%$ and poor outcome ( $\mathrm{mRS} 3-6$ ) in $42.0 \%$ of patients; $16 \%$ of patients died.

Relationships between risk factors, the status of patients on admission according to NIHSS, radiologi- 
cal signs in the first CT and type of IS according to OCSP classification and good clinical outcome at 3 months according to mRS (0-2), case-fatalities during 3 months of onset and SICH by ECASS II definition are presented in Tables 3-5.

Groups of patients with good and poor outcome, with and without SICH and groups of patients who died and who survived did not differ according to the presence of vascular risk factors, used antiplatelet or anticoagulant medications at stroke onset and onset-to-needle time.

Good outcome (mRS 0-2) at 3 months was related to younger age $(p=0.001)$, male sex $(p=0.02)$ and low scores on the NIHSS $(<15$ points $)(p<0.0001)$. Deaths within 3 months were related to older age ( $p=0.027$ ), female sex ( $p=0.004)$, severity of neurological deficit measured on the NIHSS $(p<0.0001)$, baseline systolic blood pressure $(p=0.003$ ) and presence of radiological signs of previous stroke in baseline $\mathrm{CT}(p=0.002)$.

The group of patients with SICH exhibited older age $(p=0.014)$ and higher severity of neurological deficit measured on the NIHSS ( $p=0.03)$, as well as higher serum glucose on admission $(p=0.044)$. SICH was more frequent in women $(p=0.043)$.

Total anterior circulation infarct (TACI) was related to poor outcome $(p<0.0001)$, death $(p<0.0001)$ and $\operatorname{SICH}(p=0.006)$.

\section{Discussion}

In the analysed cohort of patients with IS treated with intravenous thrombolysis, $52.4 \%$ of patients were functionally independent (mRS $0-2$ ) and $16.2 \%$ died at 90 -day follow-up. The proportion of independency for the NINDS trial was $39 \%$ and mortality was $17 \%$; for pooled randomized control trials those numbers were $50.1 \%$ and $17.3 \%$; for the ECASS II trial $-54.3 \%$ and $10.6 \%$; for SITS-MOST $-50.4 \%$ and $15.5 \%$, respectively $[5,18-20]$. In the first published report from our country in a group of 100 cases of patients treated with rt-PA, $61 \%$ had favourable functional outcome with an $\mathrm{mRS}$ of $0-2$ and $14 \%$ of patients died [13]. Of note, our patients were older and had higher mean NIHSS scores than a group of patients from the $2^{\text {nd }}$ Department of Neurology of the Institute of Psychiatry and Neurology [21].

Kent et al. [22] using data from 5 major randomized clinical trials $(n=2184)$ with alteplase in the 0-6hour window showed that, in addition to rt-PA treatment, seven variables significantly affected prognosis and/or the treatment effect with rt-PA: age, diabetes,
Table 2. Radiological findings in studied patients

\begin{tabular}{|ll|}
\hline Variable & N (\%) \\
\hline Signs of old stroke in baseline CT & $73(36.5 \%)$ \\
\hline \begin{tabular}{l} 
Signs of acute stroke in baseline CT \\
\hline Total
\end{tabular} & $55(27.5 \%)$ \\
\hline Hyperdense artery sign & $18(9.0 \%)$ \\
\hline Basal ganglia obscuration & $35(17.5 \%)$ \\
\hline Sylvian fissure obscuration & $19(9.5 \%)$ \\
\hline $\begin{array}{l}\text { Haemorrhagic transformation in control } \\
\text { (2 and 7 days)* }\end{array}$ & $35(17.5 \%)$ \\
\hline \begin{tabular}{l} 
Haemorrhagic infarct type 1 \\
\hline Paremorrhagic infarct type 2
\end{tabular} & $7(3.5 \%)$ \\
\hline \begin{tabular}{l} 
Parenchymal haematoma type 1 haematoma type 2 \\
\hline Parenchymal haematoma remote type 1
\end{tabular} & $8(4.0 \%)$ \\
\hline Parenchymal haematoma remote type 2 & 0 \\
\hline Symptomatic intracerebral haemorrhage** & $10(5 \%)$ \\
\hline $\begin{array}{l}\text { Cerebral oedema in control CT } \\
(2 \text { and } 7 \text { days) }\end{array}$ & $8(4.0 \%)$ \\
\hline \begin{tabular}{l} 
Total \\
\hline Cerebral oedema 1
\end{tabular} & $64(32 \%)$ \\
\hline Cerebral oedema 2 & $26(13 \%)$ \\
\hline
\end{tabular}

*According to the ECASS II criteria

**According to SITS Monitoring Study (SITS-MOST) Final Study Protocol $C T$ - computed tomography

stroke severity, sex, previous stroke, systolic blood pressure, and time from symptom onset. Catastrophic outcome was predicted only by age, stroke severity and serum glucose [22].

We found that male sex was associated with good outcome, with decreased mortality and with lower incidence of SICH. Our observations are opposite to data from the pooled analysis by Kent et al. and other studies $[22,23]$. Median age in our patients was significantly lower in the group of patients with good outcome after 3 months from stroke onset, and higher in the group of patients who died within 3 months and in patients with SICH. The data from the Austrian Stroke Unit Registry showed that age emerged as a highly significant inverse predictor of good functional outcome after ischaemic stroke independent of stroke severity and other factors [24]. Older age was one of the independent predictors of mortality at 3 and 12 months in the Bern 
Table 3. Baseline characteristics of patients treated with alteplase according to the main outcome variables - patients with good versus poor outcome at 3 months

\begin{tabular}{|c|c|c|c|c|}
\hline & $\begin{array}{l}\text { Patients with good } \\
\text { outcome (mRS 0-2 } \\
\text { at } 3 \text { months affer } \\
\text { stroke onset) } \\
n=116\end{array}$ & $\begin{array}{l}\text { Patients with poor } \\
\text { outcome (mRS 3-6 } \\
\text { at } 3 \text { months after } \\
\text { stroke onset) } \\
n=84\end{array}$ & $\begin{array}{l}\text { Odds ratio } \\
(95 \% \mathrm{Cl})\end{array}$ & $P$-value \\
\hline Age [years]; mean & 66.9 & 71.5 & & 0.001 \\
\hline Men & $62.9 \%$ & $46.4 \%$ & $0.51(0.29-0.90)$ & 0.02 \\
\hline Hypertension & $68.1 \%$ & $65.5 \%$ & $1.13(0.62-2.04)$ & 0.70 \\
\hline Diabetes mellitus & $13.8 \%$ & $10.7 \%$ & $1.33(0.56-3.18)$ & 0.52 \\
\hline Dyslipidaemia* & $75.9 \%$ & $78.6 \%$ & $0.86(0.44-1.68)$ & 0.66 \\
\hline Atrial fibrillation (paroxysmal and persistent) & $30.2 \%$ & $39.3 \%$ & $0.67(0.37-1.21)$ & 0.18 \\
\hline Coronary heart disease & $56.0 \%$ & $47.6 \%$ & $1.40(0.8-2.46)$ & 0.24 \\
\hline Previous stroke & $12.9 \%$ & $21.4 \%$ & $0.55(0.26-1.16)$ & 0.11 \\
\hline Current smoker & $24.1 \%$ & $14.3 \%$ & $1.91(0.91-4.02)$ & 0.09 \\
\hline Previous smoker & $19.0 \%$ & $19.1 \%$ & $0.89(0.43-1.83)$ & 0.74 \\
\hline Aspirin or other antiplatelet agent at stroke onset & $56.0 \%$ & $60.7 \%$ & $0.83(0.47-1.46)$ & 0.51 \\
\hline Oral anticoagulant at stroke onset & $14.7 \%$ & $16.7 \%$ & $0.86(0.4-1.86)$ & 0.70 \\
\hline Blood glucose $[\mathrm{mmol} / \mathrm{L}]$; mean & 6.90 & 6.96 & & 0.37 \\
\hline Systolic blood pressure $>160 \mathrm{~mm} \mathrm{Hg}$ & $28.5 \%$ & $48.8 \%$ & $0.42(0.23-0.75)$ & 0.003 \\
\hline Diastolic blood pressure $>90 \mathrm{~mm} \mathrm{Hg}$ & $20.7 \%$ & $32.1 \%$ & $0.55(0.29-1.05)$ & 0.07 \\
\hline \multicolumn{5}{|l|}{ NIHSS score } \\
\hline$\leq 7$ & $30.2 \%$ & $9.5 \%$ & $4.11(1.79-9.41)$ & 0.001 \\
\hline $8-14$ & $52.6 \%$ & $34.5 \%$ & $2.10(1.18-3.75)$ & 0.01 \\
\hline$>14$ & $17.2 \%$ & $56.0 \%$ & $0.16(0.09-0.31)$ & $<0.0001$ \\
\hline \multicolumn{5}{|l|}{ Onset-to-needle time } \\
\hline$\leq 90 \mathrm{~min}$ & $6.9 \%$ & $9.5 \%$ & $0.70(0.25-1.96)$ & 0.50 \\
\hline $91-180 \mathrm{~min}$ & $78.5 \%$ & $85.7 \%$ & $0.61(0.29-1.29)$ & 0.19 \\
\hline $181-270 \mathrm{~min}$ & $12.9 \%$ & $4.8 \%$ & $2.97(0.95-9.3)$ & 0.05 \\
\hline Signs of old stroke in baseline CT & $20.7 \%$ & $53.6 \%$ & $0.28(0.15-0.51)$ & $<0.0001$ \\
\hline Signs of current stroke in baseline CT & $20.7 \%$ & $36.9 \%$ & $0.45(0.24-0.84)$ & 0.01 \\
\hline \multicolumn{5}{|l|}{ Clinical stroke syndromes } \\
\hline TACI & $12.9 \%$ & $46.4 \%$ & $0.17(0.09-0.34)$ & $<0.0001$ \\
\hline PACI & $57.8 \%$ & $38.9 \%$ & $1.91(1.08-3.38)$ & 0.025 \\
\hline
\end{tabular}

*According to European guidelines on cardiovascular disease prevention in clinical practice

$m R S$ - modified Rankin Scale; CI - confidence interval; CT - computed tomography; NIHSS - National Institutes of Health Stroke Scale; TACI - total anterior circulation infarct; $P A C I$ - partial anterior circulation infarct

Stroke Project [25]. Increasing age was associated with increased in-hospital mortality also in patients from the German Stroke Register Study [26].

Our analyses showed no negative impact of vascular risk factors on the long-term outcome, mortality rate or the presence of SICH in patients with acute IS treated with intravenous thrombolysis. We also did not find any relation between a history of diabetes or baseline serum glucose and poor outcome and death. The high baseline glucose level had a statistically significant effect 
Table 4. Baseline characteristics of patients treated with alteplase according to the main outcome variables - survivors versus deceased within 3 months after stroke onset

\begin{tabular}{|c|c|c|c|c|}
\hline & $\begin{array}{l}\text { Patients who survived } \\
3 \text { months after } \\
\text { stroke onset } \\
n=169\end{array}$ & $\begin{array}{l}\text { Patients who died } \\
\text { within } 3 \text { months } \\
\text { after stroke onset } \\
\quad n=31\end{array}$ & $\begin{array}{l}\text { Odds ratio } \\
\text { (95\% Cl) }\end{array}$ & $P$-value \\
\hline Age [years]; mean & 68.3 & 73.1 & & 0.03 \\
\hline Men & $60.4 \%$ & $32.3 \%$ & $3.20(1.42-7.21)$ & 0.004 \\
\hline Hypertension & $67.5 \%$ & $64.5 \%$ & $0.88(0.39-1.96)$ & 0.75 \\
\hline Diabetes mellitus & $12.4 \%$ & $13.3 \%$ & $1.04(0.33-3.28)$ & 0.83 \\
\hline Dyslipidaemia* & $77.5 \%$ & $74.2 \%$ & $0.83(0.35-2.01)$ & 0.69 \\
\hline Atrial fibrillation (paroxysmal and persistent) & $32.5 \%$ & $41.9 \%$ & $1.50(0.68-3.27)$ & 0.31 \\
\hline Coronary heart disease & $52.1 \%$ & $54.8 \%$ & $1.12(0.52-2.41)$ & 0.77 \\
\hline Previous stroke & $15.4 \%$ & $22.6 \%$ & $1.60(0.63-4.11)$ & 0.32 \\
\hline Current smoker & $20.7 \%$ & $16.1 \%$ & $0.74(0.26-2.06)$ & 0.56 \\
\hline Previous smoker & $19.5 \%$ & $9.7 \%$ & $0.44(0.13-1.54)$ & 0.19 \\
\hline Aspirin or other antiplatelet agent at stroke onset & $56.8 \%$ & $64.5 \%$ & $1.38(0.62-3.07)$ & 0.42 \\
\hline Oral anticoagulant at stroke onset & $16.0 \%$ & $12.9 \%$ & $0.78(0.25-2.41)$ & 0.87 \\
\hline Blood glucose $[\mathrm{mmol} / \mathrm{L}]$; mean & 6.86 & 7.28 & & 0.33 \\
\hline Systolic blood pressure $>160 \mathrm{~mm} \mathrm{Hg}$ & $34.3 \%$ & $51.6 \%$ & $2.04(0.94-4.42)$ & 0.07 \\
\hline Diastolic blood pressure $>90 \mathrm{~mm} \mathrm{Hg}$ & $23.7 \%$ & $36.7 \%$ & $1.77(0.78-4.01)$ & 0.17 \\
\hline \multicolumn{5}{|l|}{ NIHSS score } \\
\hline$\geq 7$ & $23.7 \%$ & $9.7 \%$ & $0.35(0.10-1.2)$ & 0.08 \\
\hline $8-14$ & $50.3 \%$ & $16.1 \%$ & $0.19(0.07-0.52)$ & 0.0004 \\
\hline$>14$ & $26.0 \%$ & $74.2 \%$ & $8.17(3.41-19.6)$ & $<0.0001$ \\
\hline \multicolumn{5}{|l|}{ Onset-to-needle time } \\
\hline$\geq 90 \mathrm{~min}$ & $7.1 \%$ & $12.9 \%$ & $1.94(0.58-6.46)$ & 0.46 \\
\hline $91-180 \mathrm{~min}$ & $82.7 \%$ & $77.4 \%$ & $0.74(0.29-1.88)$ & 0.53 \\
\hline $181-270 \mathrm{~min}$ & $9.5 \%$ & $9.7 \%$ & $1.03(0.28-3.75)$ & 0.77 \\
\hline Signs of old stroke in baseline CT & $32.1 \%$ & $61.3 \%$ & $3.37(1.53-7.44)$ & 0.002 \\
\hline Signs of current stroke in baseline $\mathrm{CT}$ & $25.0 \%$ & $41.9 \%$ & $2.18(0.99-4.83)$ & 0.05 \\
\hline \multicolumn{5}{|l|}{ Clinical stroke syndromes } \\
\hline TACI & $20.2 \%$ & $64.5 \%$ & $7.22(3.16-16.5)$ & $<0.0001$ \\
\hline PACI & $54.8 \%$ & $32.3 \%$ & $0.40(0.18-0.9)$ & 0.023 \\
\hline
\end{tabular}

* According to European guidelines on cardiovascular disease prevention in clinical practice

CI - confidence interval; CT - computed tomography; NIHSS - National Institutes of Health Stroke Scale; TACI - total anterior circulation infarct; PACI - partial anterior circulation infarct

on the presence of SICH. In patients with acute IS from both parts of the NINDS trial, higher admission glucose levels were associated with significantly lower odds for desirable clinical outcomes and significantly higher odds for symptomatic intracerebral haemorrhage, regardless of treatment with alteplase [27]. High blood glucose was significantly higher in the group of patients with SICH in the ECASS II trial [18]. Lansberg et al. [28] conducted a meta-analysis of twelve studies which met inclusion criteria of a systematic review. Elevated 
Table 5. Baseline characteristics of patients treated with alteplase according to the main outcome variables - patients with symptomatic intracerebral haemorrhage (SICH) versus patients without $\mathrm{SICH}$

\begin{tabular}{|c|c|c|c|c|}
\hline & $\begin{array}{l}\text { Patients with SICH } \\
\text { ccording to ECASS II } \\
\text { definition) } \\
n=10\end{array}$ & $\begin{array}{c}\text { Patients without SICH } \\
\text { (according to ECASS II } \\
\text { definition) } \\
n=190\end{array}$ & $\begin{array}{l}\text { Odds ratio } \\
(95 \% \mathrm{Cl})\end{array}$ & $P$-value \\
\hline Age [years]; mean & 77.9 & 68.6 & & 0.01 \\
\hline Men & $20.0 \%$ & $57.9 \%$ & $5.5(1.14-26.6)$ & 0.05 \\
\hline Hypertension & $50.0 \%$ & $67.9 \%$ & $0.47(0.13-1.70)$ & 0.41 \\
\hline Diabetes mellitus & $33.3 \%$ & $24.4 \%$ & $3.27(0.79-13.6)$ & 0.22 \\
\hline Dyslipidaemia* & $80.0 \%$ & $76.8 \%$ & $1.21(0.25-5.89)$ & 0.88 \\
\hline Atrial fibrillation (paroxysmal and persistent) & $50.0 \%$ & $33.2 \%$ & $2.02(0.56-7.22)$ & 0.45 \\
\hline Coronary heart disease & $40.0 \%$ & $53.2 \%$ & $0.59(0.16-2.15)$ & 0.63 \\
\hline Previous stroke & 0 & $36.7 \%$ & & 0.31 \\
\hline Current smoker & $10.0 \%$ & $20.5 \%$ & $0.43(0.05-3.5)$ & 0.69 \\
\hline Previous smoker & $10.0 \%$ & $18.4 \%$ & $0.49(0.06-4.01)$ & 0.80 \\
\hline Aspirin or other antiplatelet agent at stroke onset & $60.0 \%$ & $57.9 \%$ & $1.09(0.3-3.99)$ & 0.84 \\
\hline Oral anticoagulant at stroke onset & $10.0 \%$ & $15.8 \%$ & $0.59(0.07-4.85)$ & 0.96 \\
\hline Blood glucose $[\mathrm{mmol} / \mathrm{L}]$; mean & 8.51 & 6.84 & & 0.044 \\
\hline Systolic blood pressure $>160 \mathrm{~mm} \mathrm{Hg}$ & $50.0 \%$ & $36.3 \%$ & $1.75(0.49-6.27)$ & 0.59 \\
\hline Diastolic blood pressure $>90 \mathrm{~mm} \mathrm{Hg}$ & $50.0 \%$ & $24.2 \%$ & $3.13(0.87-11.3)$ & 0.15 \\
\hline \multicolumn{5}{|l|}{ NIHSS score } \\
\hline$\leq 7$ & $10.0 \%$ & $22.1 \%$ & $0.39(0.05-3.18)$ & 0.61 \\
\hline $8-14$ & $20.0 \%$ & $46.3 \%$ & $0.29(0.06-1.4)$ & 0.19 \\
\hline$>14$ & $70.0 \%$ & $31.6 \%$ & $5.06(1.26-20.2)$ & 0.03 \\
\hline \multicolumn{5}{|l|}{ Onset-to-needle time } \\
\hline$\leq 90 \min$ & $10.0 \%$ & $7.9 \%$ & $1.30(0.15-10.9)$ & 0.72 \\
\hline $91-180 \min$ & $70.0 \%$ & $82.1 \%$ & $0.51(0.16-2.07)$ & 0.59 \\
\hline $181-270 \mathrm{~min}$ & $20.0 \%$ & $8.9 \%$ & $2.54(0.5-12.95)$ & 0.54 \\
\hline Signs of old stroke in baseline CT & $60.0 \%$ & $35.3 \%$ & $2.75(0.75-10.1)$ & 0.21 \\
\hline Signs of current stroke in baseline $\mathrm{CT}$ & $50.0 \%$ & $26.3 \%$ & $2.80(0.78-10.1)$ & 0.21 \\
\hline \multicolumn{5}{|l|}{ Clinical stroke syndromes } \\
\hline TACI & $70.0 \%$ & $24.7 \%$ & $7.10(1.77-28.3)$ & 0.006 \\
\hline PACI & $30.0 \%$ & $52.1 \%$ & $0.39(0.1-1.57)$ & 0.30 \\
\hline
\end{tabular}

* According to European guidelines on cardiovascular disease prevention in clinical practice

ECASS - European Cooperative Acute Stroke Study; CI - confidence interval; CT - computed tomography; NIHSS - National Institutes of Health Stroke Scale; TACI - total anterior circulation infarct; PACI - partial anterior circulation infarct

serum glucose and history of diabetes were independent risk factors for thrombolysis-associated SICH in six of the twelve studies [28].

We found that baseline patient's status (NIHSS > 14 points) and type of stroke according to the OCSP classification (TACI) are related to elevated risk of SICH. Higher NIHSS score was identified as an independent risk factor of SICH in several previous studies [5,29, 30]. Kablau et al. [31] showed that the development of haemorrhagic transformation was associated with a more 
severe neurological deficit on admission and territorial infarction.

Patients with radiological signs of previous stroke in baseline CT also had higher risk of death within 3 months. We did not find a statistically significant correlation between signs of current stroke at baseline CT and risk of death or SICH. However, it was an independent risk factor of SICH in the ECASS II study [32]. No association of early ischaemic changes with $\mathrm{SICH}$ at 36 hours was detected in the group treated with rt-PA from the NINDS trial [33].

\section{Conclusions}

The indications for intravenous thrombolysis in patients with IS should be strictly analysed so that the treatment is effective and safe, especially in older patients, patients with significant severity of neurological symptoms and patients with old post-stroke lesions in baseline CT.

\section{Disclosure}

Authors report no conflict of interest.

\section{References}

1. Lloyd-Jones D., Adams R.J., Brown T.M., et al. Executive summary: heart disease and stroke statistics-2010 update: a report from the American Heart Association. Circulation 2010; 12: 948-954.

2. Członkowska A., Ryglewicz D. Epidemiology of cerebral stroke in Poland. Neurol Neurochir Pol 1999; 32 (Suppl 6): 99-103.

3. Członkowska A., Ryglewicz D., Weissbein T., et al. A prospective community-based study of stroke in Warsaw, Poland. Stroke 1994; 25: 547-55 .

4. Ryglewicz D., Milewska D. Epidemiologia udaru mózgu. In: Mazur R., Książkiewicz B., Nyka W.M. [eds.]. Wyd. 2. Udar mózgu w praktyce lekarskiej. Via Medica, Gdańsk 2010, pp. 5-14.

5. The National Institute of Neurological Disorders and Stroke rt-PA Stroke Study Group. Tissue plasminogen activator for acute ischemic stroke. $N$ Engl J Med 1995; 333: 1581-1587.

6. Wahlgren N., Ahmed N., Davalos A., et al. Thrombolysis with alteplase for acute ischemic stroke in the Safe Implementation of Thrombolysis in Stroke-Monitoring Study (SITS-MOST): an observational study. Lancet 2007; 369: 275-282.

7. Kobayahi A., Skowrońska A., Litwin T., et al. Lack of experience of intravenous thrombolysis for acute ischaemic stroke does not influence the proportion of patients treated. Emerg Med J 2007; 24: 96-99.

8. Hacke W., Donnan G., Fieschi C., et al. Association of outcome with early stroke treatment: pooled analysis of ATLANTIS ECASS, and NINDS rt-PA stroke trials. Lancet 2004; 363: 768-774.
9. Hacke W., Kaste M., Bluhmki E., et al. Thrombolysis with alteplase 3 to 4,5 hours after acute ischaemic stroke. $N$ Engl J Med 2008; 359: 1317-1329.

10. Wahlgren N., Ahmed N., Davelos A., et al. for the SITS investigators. Thrombolysis with alteplase 3 to $4,5 \mathrm{~h}$ after acute ischaemic stroke in the Safe Implementation of Treatments in Stroke Register (SITS-ISTR): an observational study. Lancet 2008; 372: 1303-1309.

11. Actilyse. Urząd Rejestracji Produktów Leczniczych, Wyrobów Medycznych i Produktów Biobójczych (URPL). Cited May 2nd, 2011; http://www.urpl.gov.pl/drugs/68220.

12. Postępowanie w udarze mózgu. Wytyczne Grupy Ekspertów Sekcji Chorób Naczyniowych Polskiego Towarzystwa Neurologicznego. Neurol Neurochir Pol 2012; 46 (Suppl 1): 24-29.

13. Członkowska A., Sarzynska-Długosz I., Niewada M., et al. Eligibility of stroke units in Poland for administration of intravenous thrombolysis. Eur J Neurol 2006; 13: 220-224.

14. Lyden P., Brott T., Tilley B,. et al. Improved reliability of the NIH Stroke Scale using video training. NINDS TPA Stroke Study Group. Stroke 1994; 25: 2220-2226.

15. Bonita R., Beaglehole R. Modification of Rankin Scale: Recovery of motor function after stroke. Stroke 1988; 19: 1497-1500.

16. von Kummer R., Allen K.L., Holle R., et al. Acute stroke: usefulness of early $\mathrm{CT}$ findings before thrombolytic therapy. Radiology 1997; 205: 327-333.

17. SITS Monitoring Study (SITS-MOST) Final Study Protocol 2002-12-18. www.acutestroke.org/...Protocol/SITS-MOST_ final_protocol[1].pdf

18. Hacke W., Kaste M., Fieschi C., et al. Randomised double-blind placebo-controlled trial of thrombolytic therapy with intravenous alteplase in acute ischaemic stroke (ECASS II). Lancet 1998; 352: $1245-1251$.

19. Wardlaw J.M., Zoppo G., Yamaguchi T., et al. Thrombolysis for acute ischaemic stroke. Cochrane Database Syst Rev 2003; 3: CD000213.

20. Wahlgren N., Ahmed N., Erikksson N., et al. Multivariable analysis of outcome predictors and adjustment of main outcome results to baseline data profile in randomized controlled trials: Safe Implementation of Thrombolysis in Stroke - Monitoring Study (SITS-MOST). Stroke 2008; 39: 3316-3322.

21. Litwin T., Kobayashi A., Skowrońska M., et al. Thrombolysis in acute ischaemic stroke within 3 hours of symptom onset: a report of the first 100 cases. Neurol Neurochir Pol 2008; 42: 1-5.

22. Kent D.M., Selker H.P., Ruthazer R., et al. W. The strokethrombolytic predictive instrument: a predictive instrument for intravenous thrombolysis in acute ischemic stroke. Stroke 2006; 37: 2957-2962.

23. Saposnik G., Di Legge S., Webster F., et al. Predictors of major neurologic improvement after thrombolysis in acute stroke. Neurology 2005; 65: 1169-1174.

24. Knoflach M., Matosevic B., Rücker M., et al. Functional recovery after ischemic stroke - a matter of age. Data from the Austrian Stroke Unit Registry. Neurology 2012; 78: 279-285.

25. Fischer U., Mono M.L., Zwahlen M., et al. Impact of thrombolysis on stroke outcome at 12 months in a population: the Bern stroke project. Stroke 1012; 43: 1039-1045. 
26. Heuschmann P.U., Kolominsky-Rabas P.L., Roether J., et al. for the German Stroke Register Study Group. Predictors of inhospital mortality in patients with acute ischemic stroke treated with thrombolytic therapy. JAMA 2004; 292: 1831-1838.

27. Bruno A., Levine S.R., Frankel M.R., et al. Admission glucose level and clinical outcomes in the NINDS rt-PA Stroke Trial. Neurology 2002; 59: 669-674.

28. Lansberg M.G., Albers G.W., Wijman C.A.C. Symptomatic intracerebral hemorrhage following thrombolytic therapy for acute ischemic stroke: a review of the risk factors. Cerebrovasc Dis 2007; 24: 1-10.

29. Fiorelli M., Bastianello S., von Kummer R., et al. Hemorrhagic transformation within 36 hours of a cerebral infarct: relationships with early clinical deterioration and 3-month outcome in the European Cooperative Acute Stroke Study I (ECASS I) cohort. Stroke 1999; 30: 2280-2284.

30. Cocho D., Borrell M., Marti-Fabregas J., et al. Pretreatment hemostatic markers of symptomatic intracerebral hemorrhage in patients treated with tissue plasminogen activator. Stroke 2006; 37: 996-999.

31. Kablau M., Kreisel S.H., Sauer T., et al. Predictors et early outcome of hemorrhagic transformation after acute ischemic stroke. Cerebrovasc Dis 2011; 32: 334-341.

32. Larrue V., von Kummer R., Müller A., et al. Risk factors for severe hemorrhagic transformation in ischemic stroke patients treated with recombinant tissue plasminogen activator: a secondary analysis of the European-Australasian Acute Stroke Study ECASS II. Stroke 2001; 32: 438-441.

33. Patel S.C., Levine S.R., Tilley B.C., et al. Lack of clinical significance of early ischemic changes on computed tomography in acute stroke. JAMA 2001; 286: 2830-2838. 